\title{
The Antinociceptive Action of Aqueous Extract from Muntingia calabura Leaves: The Role of Opioid Receptors
}

\author{
Zainul Amiruddin Zakariaa, b Safarul Mustaphac Mohd. Roslan Sulaiman ${ }^{\mathrm{b}}$ \\ Abdul Manan Mat Jais ${ }^{b} \quad$ Muhammad Nazrul Somchit $^{b}$ Fatimah Corazon Abdullah ${ }^{a}$ \\ ${ }^{a}$ Faculty of Biotechnology and Life Sciences, Universiti Industri Selangor, ${ }^{b}$ Department of Biomedical Sciences, \\ Faculty of Medicine and Health Science, Universiti Putra Malaysia, and ' University College of Technology and \\ Management, Selangor, Malaysia
}

\section{Key Words}

Muntingia calabura $\cdot$ Antinociceptive activity $\cdot$ Abdominal constriction test $\cdot$ Hot-plate test $\cdot$ Temperature effect . Opioid receptor

\begin{abstract}
Objective: The present study was carried out to investigate the antinociceptive activity of the aqueous extract of Muntingia calabura (MCAE) leaves and to determine the effect of temperature and the involvement of the opioid receptor on the said activity using the abdominal constriction test (ACT) and hot-plate test (HPT) in mice. Materials and Methods: The extract was prepared by soaking the dried powdered leaves of $M$. calabura in distilled water $\left(\mathrm{dH}_{2} \mathrm{O}\right)$ overnight, and the supernatant obtained was considered as a stock solution with $100 \%$ concentration. The stock solution was diluted to $1,5,10,50$ and $100 \%$ and used to determine the antinociceptive activity of MCAE. A further experiment was done with $50 \%$ concentration to determine the effect of temperature and naloxone involvement of the opioid receptor system in MCAE antinociceptive activity. Results: At the various concentrations MCAE showed significant antinociceptive activity in both tests. However, the concentrationdependent activity was observed only in the ACT but not in the HPT. The $50 \%$ concentration of MCAEs were also stable
\end{abstract}

against the effect of various temperatures as indicated by the presence of activity in both tests. The temperatures (40, 60 and $100^{\circ} \mathrm{C}$ ) also showed an enhanced extract activity only in the HPT. Pre-treatment with naloxone ( 2 and $10 \mathrm{mg} /$ $\mathrm{kg}$ ) blocked the extract activity in both tests, indicating the involvement of the opioid receptor system in MCAE antinociceptive activity. Conclusion: Our data indicate that M. calabura leaves possess antinociceptive activity against chemically and thermally induced noxious stimuli. The bioactive compound(s) responsible for its antinociceptive activity is/ are heat-stable and work partly via the opioid receptor system.

Copyright @ 2007 S. Karger AG, Basel

\section{Introduction}

Muntingia calabura L., also known as 'kerukup siam' to the Malays, is a plant of the family Elaeocarpaceae [1]. Although it is not native to Southeast Asia and usually not cultivated, it has become one of the most common roadside trees in the region after its initial introduction to the Philippines [2]. The fruits, sometimes eaten fresh, are often cooked in tarts or made into jam, while the leaf infusion is drunk as a tea-like beverage [1]. Traditionally, the flowers are said to possess antiseptic properties and

\section{KARGER}

Fax +41 613061234

E-Mail karger@karger.ch

www.karger.com
(C) 2007 S. Karger AG, Basel

$1011-7571 / 07 / 0162-0130 \$ 23.50 / 0$

Accessible online at:

www.karger.com/mpp
Zainul Amiruddin Zakaria

School of Biotechnology and Life Sciences, Universiti Industri Selangor

Jalan Zirkon A 7/A, Seksyen 7

40000 Shah Alam, Selangor (Malaysia)

Tel. +60 35522 3590, Fax +60 35513 7959, E-Mail shaza8174@yahoo.com 
an infusion of the flowers is valued as an antispasmodic. It is taken to relieve headache and the first symptoms of a cold $[2,3]$. According to Peruvian folklore, its leaves can either be boiled or steeped in water to provide relief from gastric ulcers or to reduce swelling of the prostate gland, respectively [1]. Furthermore, the strips of its bark are boiled and used as a wash to reduce swelling in the lower extremities. There are not many scientific articles published on this plant extract, thereby indicating lack of exploration into its pharmaceutical benefits. There are several scientific papers reporting on the anti-tumour properties of the leaves [4] and roots [5] of M. calabura. Based on the fact that M. calabura grows wild in Malaysia and that adequate studies have not been carried out to explore the pharmaceutical benefits of this plants, we decided to evaluate and establish some of the basic pharmaceutical properties of this plant, focusing on its antinociceptive activity. The aim of the present study was therefore to elucidate the mechanism of antinociceptive activity of the aqueous extract of $M$. calabura (MCAE) leaves in mice using the abdominal constriction and hot-plate tests.

\section{Materials and Methods}

\section{Experimental Animals}

Male ICR mice (25-30 g; 5-7 weeks old) were used in this study. The animals were obtained from the Veterinary Animal Unit, Faculty of Veterinary Medicine, Universiti Putra Malaysia (UPM), Malaysia and kept at room temperature $\left(27 \pm 2{ }^{\circ} \mathrm{C} ; 70-\right.$ $80 \%$ humidity; 12 -hour light/darkness cycle) in the Animal Holding Unit for at least $48 \mathrm{~h}$ before use. Food and water were supplied ad libitum up to the beginning of the experiments. At all times the mice were handled in accordance with current UPM guidelines for the care of laboratory animals and the ethical guidelines for investigations of experimental pain in conscious animals. All experiments $(n=10)$ were conducted between 09.30 and $18.30 \mathrm{~h}$ to minimize the effects of environmental changes.

\section{Preparation of Drugs}

$100 \mathrm{mg} / \mathrm{kg}$ acetylsalicylic acid (ASA, Bayer, Singapore), $0.8 \mathrm{mg} / \mathrm{kg}$ or $5 \mathrm{mg} / \mathrm{kg}$ morphine sulfate (Sigma, Germany) and 2 and $10 \mathrm{mg} / \mathrm{kg}$ naloxone (Sigma, Germany) were prepared by dissolving the powder in distilled water $\left(\mathrm{dH}_{2} \mathrm{O}\right) .0 .8 \mathrm{mg} / \mathrm{kg}$ morphine was used in the abdominal constriction test while $5 \mathrm{mg} / \mathrm{kg}$ morphine was used in the hot-plate test.

\section{Plant Material}

The leaves of M. calabura were collected in January and February 2004 from its natural habitat in Shah Alam, Selangor, Malaysia and identified by Mr. Shamsul Khamis, a botanist from the Institute of Bioscience, UPM, Malaysia. A voucher specimen (SK 964/04) was deposited at the Herbarium of the Laboratory of Natural Products, Institute of Bioscience, UPM, Serdang, Selangor, Malaysia.

Muntingia calabura Extract

Antinociception in Mice

\section{Preparation of MCAE}

The leaves of M. calabura were washed and rinsed with water to remove all the dirt and unwanted particles and then oven-dried for $72 \mathrm{~h}$ at the temperature of $40^{\circ} \mathrm{C}$. The dried leaves were then ground into small particles, weighed and mixed with $\mathrm{dH}_{2} \mathrm{O}$ at the ratio of 1:25 (w/v). This mixture was then left for $24 \mathrm{~h}$ and the supernatant was collected and filtered using Whatman No. 1 filter paper while the remaining plant residue was kept in an oven for future use. The supernatant obtained, labelled as MCAE and considered as stock solution with $100 \%$ concentration, was diluted to the concentrations of $1,5,10$, and $50 \%$ with $\mathrm{dH}_{2} \mathrm{O}$ for antinociceptive study. A $30-\mathrm{ml}$ volume of the obtained supernatant divided equally ( $10 \mathrm{ml}$ each) was put into three plastic test tubes and then subjected to a freezing-drying process to determine the amount of crude dried MCAE present in every $10 \mathrm{ml}$ of the supernatant.

\section{Antinociceptive Studies}

Preliminary Studies. A preliminary experiment to determine the antinociceptive activity of MCAE was performed after subcutaneous (s.c.) administration of various concentrations (1, 5, 10, 50 and $100 \%)$ with water $\left(\mathrm{dH}_{2} \mathrm{O}\right)$ as a control group, and ASA and morphine as reference drugs at room temperature $\left(27 \pm 2{ }^{\circ} \mathrm{C}\right)$. Based on the result of this preliminary experiment, the effects of temperature and naloxone on the antinociceptive activity of MCAE were tested only at $50 \%$ concentration. The extract was preheated for $2 \mathrm{~h}$ at $40,60,80$ or $100^{\circ} \mathrm{C}$, then left to cool to room temperature before being administered subcutaneously to the mice. For the effect of naloxone, the mice were pre-treated subcutaneously with $\mathrm{dH}_{2} \mathrm{O}$ or naloxone $(2 \mathrm{or} 10 \mathrm{mg} / \mathrm{kg}$ ) followed $5 \mathrm{~min}$ later by $\mathrm{dH}_{2} \mathrm{O}$, morphine $(0.8$ or $5 \mathrm{mg} / \mathrm{kg})$ or the $50 \%$ MCAE solution. All the solutions and drugs were administered to the mice in a volume of $10 \mathrm{mg} / \mathrm{kg}$.

Abdominal Constriction Test. The abdominal constriction test [6] was used to evaluate the peripheral antinociceptive activity and to determine the role of temperature and opioid receptors on the respective activity of MCAE. Groups of 10 mice were used for controls and tests. Briefly, the animals were injected (s.c.) with $\mathrm{dH}_{2} \mathrm{O}$, ASA, morphine or MCAE $(1,5,10,50$ or $100 \%)$ followed by intraperitoneal administration of $0.6 \%$ acetic acid (J.T. Baker, USA) $30 \mathrm{~min}$ later. The mice were placed individually into glass beakers and 5 min were allowed to elapse. The number of abdominal constrictions produced in these animals was counted for $25 \mathrm{~min}$. Abdominal constrictions resulted from the injection of acetic acid and consisted of a contraction of abdominal muscles together with a stretching of at least one hind limb [7]. Antinociceptive activity, indicated by a reduction in the mean number of abdominal constrictions in the test groups compared to the control group, was calculated as the percentage inhibition of abdominal constrictions (percentage of inhibitory level) using the following formula [8]:

\section{Mean of (control - test group)/control group $\times 100 \%$}

Hot-Plate Test. The hot-plate test described by Wilson et al. [9] with slight modification was used to assess central antinociceptive properties of MCAE and the factors described earlier that may influence its activity. The temperature of the metal surface (Model 7280, Ugo Basile, Italy) was maintained at $50 \pm 0.2^{\circ} \mathrm{C}$. Latency to a discomfort reaction (licking paws or jumping) was determined before and after drug administration. The cut-off 
Table 1. Antinociceptive activity profiles of MCAE in mice assessed using the abdominal constriction test

\begin{tabular}{lcccc}
\hline Treatment & $\begin{array}{l}\text { Dosage } \\
\text { mg/kg }\end{array}$ & Mice & $\begin{array}{l}\text { Abdominal } \\
\text { constrictions } \\
\text { (mean } \pm \text { SEM) }\end{array}$ & $\begin{array}{l}\text { Analgesia } \\
\%\end{array}$ \\
\hline $\mathrm{dH}_{2} \mathrm{O}$ & - & 10 & $25.70 \pm 0.82$ & - \\
Morphine $0.8 \mathrm{mg} / \mathrm{kg}$ & 0.8 & 14 & $13.82 \pm 1.42^{\mathrm{a}}$ & 46.2 \\
$\mathrm{ASA} 100 \mathrm{mg} / \mathrm{kg}$ & 100 & 10 & $7.40 \pm 0.85^{\mathrm{a}, \mathrm{b}}$ & 71.2 \\
$\mathrm{MCAE}$ & $2.7(1 \%)$ & 10 & $23.60 \pm 1.51^{\mathrm{b}}$ & 8.2 \\
& $13.5(5 \%)$ & 10 & $15.20 \pm 0.53^{\mathrm{a}, \mathrm{b}}$ & 40.9 \\
& $27(10 \%)$ & 10 & $13.40 \pm 0.50^{\mathrm{a}, \mathrm{b}}$ & 47.9 \\
& $135(50 \%)$ & 10 & $9.40 \pm 0.91^{\mathrm{a}, \mathrm{b}}$ & 63.4 \\
& $270(100 \%)$ & 10 & $4.50 \pm 0.43^{\mathrm{a}, \mathrm{b}}$ & 82.5 \\
\hline
\end{tabular}

$\%$ equivalent concentration.

${ }^{a}$ Data differ significantly $(\mathrm{p}<0.05)$ when compared with the $\mathrm{dH}_{2} \mathrm{O}$-treated group.

${ }^{b}$ Data differ significantly $(\mathrm{p}<0.05)$ when compared with the morphine-treated group. time of $20 \mathrm{~s}$ was chosen to avoid tissue injury. Latency was recorded before and 30, 60, 120 and 180 min following s.c. administration of the agents. The prolongation of the latency times compared with the values of the controls was used for statistical comparison. Controls received $\mathrm{dH}_{2} \mathrm{O}(10 \mathrm{ml} / \mathrm{kg}$, s.c.), and morphine $(5 \mathrm{mg} / \mathrm{kg}$, s.c.) was used as a reference drug.

\section{Statistical Analysis}

The results are presented as means \pm standard error of the mean (SEM). The analysis of variance (ANOVA) test with Dunnett's post-hoc test was used to analyse and compare the data between the groups in the abdominal constriction and hot-plate tests while paired t test was used to compare data within the group in the hot-plate test, with $\mathrm{p}<0.05$ as the limit of significance.

\section{Results}

\section{Equivalent Weight of Crude Dried MCAE}

Ten milliliters of MCAE supernatant yielded approximately $0.27 \mathrm{~g}$ of crude dried extract. Simple calculation showed that the $1,5,10,50$ and $100 \%$ concentrations of MCAE were approximately equivalent to doses of 2.7 , $13.5,27,135$ and $270 \mathrm{mg} / \mathrm{kg}$, respectively. None of the concentrations of MCAE used in this study were toxic to the mice.

\section{MCAE Antinociceptive Activity Assessed by \\ Abdominal Constriction Test}

The MCAE demonstrated a significant and concentration-dependent antinociceptive activity (table 1). In addition, the activity of the $50 \%$ concentration MCAE was equieffective to that of $100 \mathrm{mg} / \mathrm{kg}$ ASA (estimated $\mathrm{IC}_{50}=$ $72.53 \mathrm{mg} / \mathrm{kg}$ ) while the $10 \%$ concentration MCAE activ-
Table 2. Effect of temperature on MCAE antinociceptive activity in mice assessed using the abdominal constriction test

\begin{tabular}{lcccc}
\hline Treatment & $\begin{array}{l}\text { Tempera- } \\
\text { ture, }{ }^{\circ} \mathrm{C}\end{array}$ & Mice & $\begin{array}{l}\text { Abdominal } \\
\text { constrictions } \\
\text { (mean } \pm \text { SEM) }\end{array}$ & $\begin{array}{l}\text { Analgesia } \\
\%\end{array}$ \\
\hline $\mathrm{dH}_{2} \mathrm{O}$ & - & 10 & $25.70 \pm 0.82$ & - \\
$50 \%$ MCAE & $\mathrm{RT}$ & 10 & $9.40 \pm 0.91^{\mathrm{a}}$ & 63.4 \\
& 40 & 10 & $11.20 \pm 1.32^{\mathrm{a}}$ & 56.4 \\
& 60 & 10 & $9.60 \pm 1.19^{\mathrm{a}}$ & 62.6 \\
& 80 & 10 & $10.20 \pm 1.06^{\mathrm{a}}$ & 60.3 \\
& 100 & 10 & $11.50 \pm 0.81^{\mathrm{a}}$ & 55.3 \\
\hline
\end{tabular}

$\mathrm{RT}=$ Room temperature $\left(27 \pm 2{ }^{\circ} \mathrm{C}\right)$.

${ }^{a}$ Data differ significantly $(\mathrm{p}<0.05)$ when compared with the $\mathrm{dH}_{2} \mathrm{O}$-treated group.

ity was equieffective to that of $0.8 \mathrm{mg} / \mathrm{kg}$ morphine (estimated $\mathrm{IC}_{50}=0.88 \mathrm{mg} / \mathrm{kg}$ ), and their analgesic effects was approximately 48 and $67 \%$, respectively. The estimated $\mathrm{IC}_{50}$ for MCAE was $12.5 \%$ concentration $(33.75 \mathrm{mg} / \mathrm{kg})$. At the highest concentration (100\%) MCAE produced approximately $82.5 \%$ analgesia. Variation in temperature did not affect the antinociceptive activity of MCAE as determined by the number of abdominal constrictions and analgesic effects (table 2).

On the other hand, pre-treatment with naloxone ( 2 or $10 \mathrm{mg} / \mathrm{kg}$ ) followed $5 \mathrm{~min}$ later by $50 \%$ concentration MCAE caused significant reversal of the respective MCAE antinociceptive activity (table 3 ). However, the lowest dosage of naloxone did not cause complete inhibi- 
Table 3. Effect of naloxone $(10 \mathrm{mg} / \mathrm{kg})$ on MCAE antinociceptive activity in mice assessed using the abdominal constriction test

\begin{tabular}{lll}
\hline Treatment & Mice & $\begin{array}{l}\text { Abdominal constric- } \\
\text { tions (mean } \pm \text { SEM) }\end{array}$ \\
\hline $\mathrm{dH}_{2} \mathrm{O}+\mathrm{dH}_{2} \mathrm{O}$ & 10 & $26.20 \pm 1.05$ \\
$\mathrm{dH}{ }_{2} \mathrm{O}+0.8 \mathrm{mg} / \mathrm{kg}$ morphine & 14 & $13.82 \pm 1.42^{\mathrm{a}}$ \\
$\mathrm{dH}{ }_{2} \mathrm{O}+50 \% \mathrm{MCAE}$ & 10 & $11.70 \pm 1.22^{\mathrm{a}}$ \\
$2 \mathrm{mg} / \mathrm{kg}$ naloxone $+\mathrm{dH}_{2} \mathrm{O}$ & 10 & $27.13 \pm 1.41$ \\
$2 \mathrm{mg} / \mathrm{kg}$ naloxone $+0.8 \mathrm{mg} / \mathrm{kg}$ morphine & 10 & $25.14 \pm 1.31$ \\
$2 \mathrm{mg} / \mathrm{kg}$ naloxone $+50 \% \mathrm{MCAE}$ & 10 & $19.73 \pm 0.93^{\mathrm{a}, \mathrm{b}}$ \\
$10 \mathrm{mg} / \mathrm{kg}$ naloxone $+\mathrm{d} \mathrm{H}_{2} \mathrm{O}$ & 10 & $25.81 \pm 1.17$ \\
$10 \mathrm{mg} / \mathrm{kg}$ naloxone $+0.8 \mathrm{mg} / \mathrm{kg}$ morphine & 10 & $26.77 \pm 1.21$ \\
$10 \mathrm{mg} / \mathrm{kg}$ naloxone $+50 \% \mathrm{MCAE}$ & 10 & $27.50 \pm 1.30$ \\
\hline
\end{tabular}

${ }^{a}$ Data differ significantly $(\mathrm{p}<0.05)$ when compared with the $\mathrm{dH}_{2} \mathrm{O}+\mathrm{dH}_{2} \mathrm{O}$-treated group.

${ }^{\mathrm{b}}$ Data differ significantly $(\mathrm{p}<0.05)$ when compared with the $2 \mathrm{mg} / \mathrm{kg}$ naloxone + $\mathrm{dH}_{2} \mathrm{O}$-treated group.

Table 4. Antinociceptive activity profiles of MCAE in mice assessed using the hot-plate test

\begin{tabular}{|c|c|c|c|c|c|c|c|}
\hline \multirow[t]{2}{*}{ Treatment } & \multirow{2}{*}{$\begin{array}{l}\text { Dose } \\
\mathrm{mg} / \mathrm{kg}\end{array}$} & \multirow[t]{2}{*}{ Mice } & \multicolumn{5}{|c|}{ Hot-plate latency, s } \\
\hline & & & 0 & 30 & 60 & 120 & 180 \\
\hline $\mathrm{dH}_{2} \mathrm{O}$ & - & 10 & $7.85 \pm 0.38$ & $8.02 \pm 0.36$ & $8.07 \pm 0.35$ & $8.70 \pm 0.23$ & $9.27 \pm 0.44^{\mathrm{b}}$ \\
\hline Morphine & 5 & 10 & $7.51 \pm 0.42$ & $10.22 \pm 1.23^{\mathrm{a}, \mathrm{c}}$ & $12.39 \pm 2.22^{\mathrm{a}, \mathrm{c}}$ & $11.03 \pm 1.39^{\mathrm{a}, \mathrm{c}}$ & $9.85 \pm 1.34^{c}$ \\
\hline \multirow[t]{5}{*}{ MCAE } & $2.7(1 \%)$ & 10 & $7.73 \pm 0.29$ & $7.45 \pm 0.31$ & $7.48 \pm 0.46$ & $10.77 \pm 0.94^{\mathrm{a}, \mathrm{c}}$ & $12.19 \pm 0.64^{\mathrm{a}, \mathrm{c}}$ \\
\hline & $13.5(5 \%)$ & 10 & $7.91 \pm 0.26$ & $7.03 \pm 0.30$ & $7.68 \pm 0.22^{\mathrm{a}}$ & $10.19 \pm 0.71^{\mathrm{a}, \mathrm{c}}$ & $13.78 \pm 0.38^{\mathrm{a}, \mathrm{c}}$ \\
\hline & $27(10 \%)$ & 10 & $7.94 \pm 0.63$ & $8.78 \pm 0.66$ & $13.04 \pm 0.92^{\mathrm{a}, \mathrm{c}}$ & $15.20 \pm 0.36^{\mathrm{a}, \mathrm{c}}$ & $14.12 \pm 0.86^{\mathrm{a}, \mathrm{c}}$ \\
\hline & $135(50 \%)$ & 10 & $8.05 \pm 0.31$ & $8.69 \pm 0.41$ & $8.25 \pm 0.77$ & $14.35 \pm 1.06^{\mathrm{a}, \mathrm{c}}$ & $12.90 \pm 0.82^{\mathrm{a}, \mathrm{c}}$ \\
\hline & $270(100 \%)$ & 10 & $7.31 \pm 0.38$ & $9.11 \pm 0.67$ & $10.55 \pm 0.67^{a, c}$ & $12.13 \pm 0.79^{a, c}$ & $15.30 \pm 0.20^{\mathrm{a}, \mathrm{c}}$ \\
\hline
\end{tabular}

${ }^{a}$ Data with this superscript differ significantly $(\mathrm{p}<0.05)$ when compared with the $\mathrm{dH}_{2} \mathrm{O}$-treated group within the respective column.

${ }^{b}$ Data with this superscript differ significantly $(\mathrm{p}<0.05)$ when compared with the 0-, 30-, 60 - and-120 min values within the respective row.

${ }^{c}$ Data with this superscript differ significantly $(\mathrm{p}<0.05)$ when compared with the 0 -min value within the respective row.

tion of MCAE antinociceptive activity as seen with the higher dosage of naloxone. After pre-treatment with $2 \mathrm{mg} / \mathrm{kg}$ naloxone MCAE still produced $15.5 \%$ analgesia.

\section{MCAE Antinociceptive Activity Assessed by}

\section{Hot-Plate Test}

The preliminary study using the hot-plate test demonstrated that MCAE possessed antinociceptive activity (table 4), which was observed $120 \mathrm{~min}$ after the administration of the lowest concentration of MCAE (1\%) and was independent of the concentration used. The $10 \%$ concentration MCAE gave the highest latency reading as early as 60 min after its administration, an activity which was not observed with the $50 \%$ concentration MCAE. All extracts exhibited their activity until the end of the experiments (180 min). Interestingly, $5 \mathrm{mg} / \mathrm{kg}$ morphine produced an onset $30 \mathrm{~min}$ after its administration but lost its activity $180 \mathrm{~min}$ later.

Variation in temperature $\left(40,60,100^{\circ} \mathrm{C}\right)$ influenced the antinociceptive activity of the extract (table 5), an effect which was not observed in the abdominal constriction test. Temperature enhanced the onset of MCAE activity as early as $60 \mathrm{~min}$ after administration. The latency of discomfort for MCAE at $40^{\circ} \mathrm{C}$ decreased significantly 
Table 5. Effect of temperature on MCAE antinociceptive activity in mice assessed using the hot-plate test

\begin{tabular}{llllllll}
\hline MCAE & $\begin{array}{l}\text { Tempera- } \\
\text { ture, }{ }^{\circ} \mathrm{C}\end{array}$ & & Mice & \multicolumn{4}{l}{ Hot-plate latency, s } \\
\cline { 3 - 7 } & & 0 & 30 & 60 & 120 & 180 \\
\hline $50 \%$ & $\mathrm{RT}$ & 10 & $8.05 \pm 0.31$ & $8.69 \pm 0.41$ & $8.25 \pm 0.77$ & $14.35 \pm 1.06^{\mathrm{c}}$ & $12.90 \pm 0.82^{\mathrm{c}}$ \\
concentration & 40 & 10 & $6.42 \pm 0.44^{\mathrm{a}}$ & $6.83 \pm 0.28^{\mathrm{a}}$ & $10.35 \pm 0.78^{\mathrm{b}, \mathrm{c}}$ & $16.30 \pm 0.68^{\mathrm{c}}$ & $15.26 \pm 0.64^{\mathrm{b}}$ \\
& 60 & 10 & $6.79 \pm 0.52$ & $8.41 \pm 0.23^{\mathrm{c}}$ & $12.46 \pm 0.618^{\mathrm{b}, \mathrm{c}}$ & $15.68 \pm 1.03^{\mathrm{c}}$ & $16.30 \pm 0.50^{\mathrm{b}}$ \\
& 80 & 10 & $6.20 \pm 0.27^{\mathrm{a}}$ & $7.21 \pm 0.45^{\mathrm{a}}$ & $8.66 \pm 0.52^{\mathrm{c}}$ & $13.24 \pm 0.59^{\mathrm{c}}$ & $13.83 \pm 1.03^{\mathrm{c}}$ \\
& 100 & 10 & $7.86 \pm 0.46$ & $9.14 \pm 0.72$ & $11.54 \pm 0.84^{\mathrm{b}, \mathrm{c}}$ & $13.72 \pm 0.98^{\mathrm{c}}$ & $10.61 \pm 0.60^{\mathrm{c}}$ \\
\hline
\end{tabular}

${ }^{a}$ Data with this superscript indicate significant decrease $(\mathrm{p}<0.05)$ in latency when compared with the MCAE prepared at RT within the respective column.

${ }^{b}$ Data with this superscript indicate significant increase $(\mathrm{p}<0.05)$ in latency when compared with the MCAE prepared at RT within the respective column.

${ }^{c}$ Data with this superscript indicate significant increase $(\mathrm{p}<0.05)$ in latency when compared with the 0 -min value within the respective row.

Table 6. Effect of naloxone $(10 \mathrm{mg} / \mathrm{kg})$ on MCAE antinociceptive activity in mice assessed using the hot-plate test

\begin{tabular}{lllllll}
\hline Treatment & \multirow{2}{*}{ Mice } & \multicolumn{4}{l}{ Hot-plate latency, $\mathrm{l}$} \\
\cline { 3 - 7 } & & 0 & 30 & 60 & 120 & 180 \\
\hline $\mathrm{dH}{ }_{2} \mathrm{O}$ & 10 & $7.67 \pm 0.65$ & $7.84 \pm 0.44$ & $7.41 \pm 0.74$ & $8.15 \pm 0.93$ & $10.45 \pm 1.27^{\mathrm{c}}$ \\
$50 \% \mathrm{MCAE}$ & 10 & $7.41 \pm 0.87$ & $7.67 \pm 0.83$ & $8.12 \pm 0.61$ & $16.21 \pm 1.46^{\mathrm{a}, \mathrm{c}}$ & $13.51 \pm 0.61^{\mathrm{a}, \mathrm{c}}$ \\
$2 \mathrm{mg} / \mathrm{kg}$ naloxone $+50 \% \mathrm{MCAE}$ & 10 & $7.21 \pm 0.51$ & $8.31 \pm 0.69$ & $7.83 \pm 0.61$ & $10.57 \pm 0.53^{\mathrm{a}-\mathrm{c}}$ & $11.89 \pm 0.97^{\mathrm{a}, \mathrm{c}}$ \\
$10 \mathrm{mg} / \mathrm{kg}$ naloxone $+50 \% \mathrm{MCAE}$ & 10 & $6.96 \pm 0.38$ & $7.21 \pm 0.45$ & $7.07 \pm 0.83$ & $10.23 \pm 0.86^{\mathrm{a}-\mathrm{c}}$ & $9.47 \pm 1.15^{\mathrm{c}}$ \\
\hline
\end{tabular}

Both dosages of naloxone did not cause significant changes in the latency of discomfort of the $\mathrm{dH}_{2} \mathrm{O}$-treated group (data not shown), and both dosages of naloxone completely blocked the morphine effect (data not shown).

${ }^{a}$ Data with this superscript differ significantly $(\mathrm{p}<0.05)$ when compared with the $\mathrm{dH}_{2} \mathrm{O}$-treated group within the respective column.

${ }^{\mathrm{b}}$ Data with this superscript differ significantly $(\mathrm{p}<0.05)$ when compared with the $50 \%$ MCAE-treated group within the respective column.

${ }^{c}$ Data with this superscript differ significantly $(\mathrm{p}<0.05)$ when compared with the 0 -min value within the respective row.

$(\mathrm{p}<0.05)$ at 0 and $30 \mathrm{~min}$. Furthermore, the MCAEs preheated at 40 and $60^{\circ} \mathrm{C}$ showed a significant $(\mathrm{p}<0.05)$ increase in activity $180 \mathrm{~min}$ after their administration when compared to the extracts prepared at room temperature. Interestingly, MCAE pre-heated at $80^{\circ} \mathrm{C}$ showed an activity that was equieffective to that of extract prepared at room temperature, except at 0 and 30 min where the former latencies of discomfort were significantly lower $(\mathrm{p}<$ $0.05)$ than the latter. Although the onset of activity of MCAE pre-heated at $100^{\circ} \mathrm{C}(60 \mathrm{~min})$ was observed earlier than that of MCAE prepared at room temperature, the latency of discomfort of the former, at 120 and $180 \mathrm{~min}$, was not significant when compared to the latter.
Pre-treatment with 2 and $10 \mathrm{mg} / \mathrm{kg}$ naloxone for $5 \mathrm{~min}$ reversed the antinociceptive activity of $50 \%$ concentration MCAE as seen at 120 min after MCAE administration (table 6). Except for the $2 \mathrm{mg} / \mathrm{kg}$ naloxone, $5 \mathrm{mg} / \mathrm{kg}$ naloxone completely blocked the MCAE antinociceptive activity at the end of the experiment. Furthermore, both concentrations of naloxone completely blocked the antinociceptive activity of $5 \mathrm{mg} / \mathrm{kg}$ morphine (data not shown). 


\section{Discussion}

The present results show that MCAE possessed antinociceptive activity when assessed using chemical- and thermal-induced pain tests. In addition, the antinociceptive activity measured using the chemically mediated test was observed to develop in a concentration-dependent manner. The abdominal constriction test has been widely used to evaluate the antinociceptive properties of drugs/extracts. According to Bentley et al. [10] the abdominal constriction test can detect analgesia of compounds/dose levels that may be inactive in the hot-plate test due to its high sensitivity. The analgesic activity observed using this assay involved, at least in part, the local peritoneal receptors, such as several different types of opioid receptors, found at the surface of the cells lining the peritoneal cavity. Furthermore, report has also been made on the expression of peripheral opioid receptors due to inflammation $[11,12]$. In contrast, the hot-plate test, which is used to investigate the central antinociceptive mechanism [13], is thought to involve the spinal reflex. Heat stimulation affects mainly the heat-sensitive nociceptors in the skin with no inflammatory response. Centrally acting drugs, like morphine, have been reported to produce an antinociceptive effect in both types of assays $[8,14]$, while peripherally acting drugs, like aspirin and indomethacin, produced an antinociceptive effect only in the abdominal constriction test $[15,16]$.

The ability of MCAE to maintain its antinociceptive activity in the abdominal constriction test or to produce greater activity after pre-treatment against a series of temperatures indicates the resistance of the bioactive compound against the effect of high temperature as reported by Dambisya et al. [17]. On the other hand, the ability of a non-selective opioid antagonist, naloxone, to reverse the extract activity in both assays indicates involvement of the opioid receptor system in the antinociceptive activity of $M$. calabura. The ability of low-dose naloxone to inhibit the MCAE antinociceptive activity in the abdominal constriction test suggests the involvement of peripheral opioid receptors $[11,12]$. The fact that the MCAE activity was not completely but significantly reversed by naloxone in the hot-plate test could be explained by a finding made by Hosseinzadeh and Amel [18]. They suggested that the extract may act at the peripheral as well as central opioid receptors both directly and indirectly, maybe by stimulating the release of endogenous opioid peptides [18]. Thus, blocking of the opioid receptors by naloxone did not stop the extract from stimulating endogenous opioid peptide release, which is expected to take some time as observed at the end of the experiments, leading to increased and prolonged antinociceptive activity. The well-known short half-life of naloxone may also be one of the factors that contribute to the above findings.

Our ongoing study has also demonstrated that the MCAE possessed anti-inflammatory and anti-pyretic activities, and inhibited the early and late phases seen in the formalin test (data not published). Further studies that have been carried out also revealed the involvement of non-opioid receptors like $\beta$-adrenergic and muscarinic receptors in MCAE antinociceptive activity when assessed using the abdominal constriction test (data not published). In addition, this activity was also found to resist the effect of extreme acidic and alkaline conditions (data not published).

The reason for using the concentrations of $1,5,10,50$ and $100 \%$ was based on our preliminary screening, that used only the last three concentrations (10, 50 and 100\%). It was found that even at the concentration of $10 \%$, the MCAE produced remarkable antinociceptive activity in the abdominal constriction test, which is approximately $50 \%$ analgesia. We carried out additional experiments using lower concentrations of MCAE to determine the minimum concentration of MCAE showing some activity. Interestingly, although the $1 \%$ concentration MCAE was not effective any more in the abdominal constriction test, it showed significant antinociceptive activity in the hot-plate test in the last $2 \mathrm{~h}$ of the experiment. The ability of tested mice to tolerate the highest concentration/ strength (100\%) extract, which is supported by Peru folklore medicinal use of the extract for treatment of various ailments [1], indicates that the aqueous extract of M. calabura was not toxic. However, it is suggested that future studies should be carried out using the doses form $(\mathrm{mg} / \mathrm{kg})$ instead of \% concentrations form, because the extract in $\mathrm{mg} / \mathrm{kg}$ form can be prepared in values greater $(>270 \mathrm{mg} / \mathrm{kg})$ than those prepared using the \% concentration form (the 100\% concentration MCAE was approximately equal to $270 \mathrm{mg} / \mathrm{kg}$ ).

Even though our study has revealed an effect of repeated heat exposure (hot-plate test) in producing antinociceptive activity in mice pre-treated with $\mathrm{dH}_{2} \mathrm{O}$, the antinociceptive activity of MCAE can still be observed and is significantly greater than that of heat exposure. The heat-induced antinociceptive activity observed may be due to some retardation of paw tissue sensitization produced by repeated testing. Although MCAE was found to inhibit both antinociceptive assays, a further study, especially one using the rota-rod test, needs to be 
carried out in the future to confirm that the extract does not interfere with the motor coordination of the animals, which has been known to influence the observed activity [13].

Although isolation and purification of different fractions of MCAE and assaying the antinociceptive activity of each fraction was not the main objective of this study, nevertheless, the said activity may also be related to the presence of various types of bioactive compounds within the leaves of plants, especially of the flavonoid type [4,5]. Furthermore, the ability of the aqueous extract to produce antinociceptive activity seems to suggest that the bioactive compounds are polar molecules. The polar compounds associated with the antinociceptive effect of aqueous extracts of plants include flavonoids [19-22], which are known to be abundant in the leaves [4]. Other studies have demonstrated that various flavonoids such as rutin, quercetin, luteolin, hesperidin and biflavonoids produce significant antinociceptive and/or anti-inflammatory activities [19-22].

\section{Conclusion}

The data obtained showed that M. calabura leaves possess heat-stable antinociceptive activity that is partly mediated by an opioid receptor.

\section{Acknowledgements}

This study was supported by a research grant from Universiti Industri Selangor, Malaysia (Project Code No. 03013; Project Vote No. 3090103013). The authors would like to thank Universiti Putra Malaysia for the facilities.

\section{References}

1 Morton JF: Fruits of Warm Climates. Miami, Morton, 1987, p 65.

2 Jensen M: Trees Commonly Cultivated in Southeast Asia: An Illustrated Field Guide, ed 2. FAO Corporate Document Repository. Bangkok, Craftsman Press, 1999.

3 Verheij EWM, Coronel RE (eds): Edible Fruits and Nuts. Plant Resources of Southeast Asia, No 2. PROSEA, Bogor, 1992.

-4 Su N, Jung Park E, Vigo JS, Graham JG, Cabiess F, Fong HH, Pezzuto JM, Kingorn AD: Activity-guided isolation of the chemical constituents of Muntingia calabura using a quinone reductase induction assay. Phytochemistry 2003;63:335-341.

$\checkmark 5$ Kaneda N, Pezzuto JM, Soejarto DD, Kinghorn AD, Farnworth NR, SantisukT, Tuchinda P, Udchachon J, Reutrakul V: Plant anticancer agents, XLVIII. New cytotoxic flavonoids from Muntingia calabura roots. J Nat Prod 1991;54:196-206.

6 Dambisya YM, Lee TL: Effects of L-NAME, L-NMMA and L-arginine on the antinociceptive effects of morphine in mice. Methods Find Exp Clin Pharmacol 1995;17:577-582.

7 Correa CR, Kyle DJ, Chakraverty S, Calixto JB: Antinociceptive profile of the pseudopeptide $\mathrm{B}_{2}$ bradykinin receptor antagonist NPC 18688 in mice. Br J Pharmacol 1996; 117:552-558.

8 Mat Jais AM, Dambisya YM, Lee TL: Antinociceptive activity of Channa striatus (haruan) in mice. J Ethnopharmacol 1997;57: 125-130. $\checkmark$ Wilson SG, Bryant CD, Lariviere WR, Olsen MS, Giles BE, Chesler EJ, Mogil JS: The heritability of antinociception. II. Pharmacogenetic mediation of three over-the-counter analgesics in mice. J Pharmacol Exp Ther 2003;305:755-764.

10 Bentley GA, Newton SH, Starr J: Evidence for an action of morphine and the enkephalins on sensory nerve endings in the mouse peritoneum. Br J Pharmacol 1981;73:325332.

11 Hassan AHS, Ableitner A, Stein C, Herz A: Inflammation of the rat paw enhances axonal transport of opioid receptors in the sciatic nerve and increases their density in the inflamed tissue. Neuroscience 1993;55:185195.

12 Schäfer M, Imai Y, Uhl GR, Stein C: Inflammation enhances peripheral $\mu$-opioid receptor-mediated analgesia, but not $\mu$-opioid receptor transcription in dorsal root ganglia. Eur J Pharmacol 1995;279:165-169.

13 Pini LA, Vitale G, Ottani A, Sandrini M: Naloxone-reversible antinociception by paracetamol in the rat. J Pharmacol Exp Ther 1996;280:934-940.

14 Sulaiman MR, Somchit MN, Israf DA, Ah$\operatorname{mad}$ Z, Moin S: Analgesic effect of Melastoma malabathricum ethanolic extract in mice. Fitoterapia 2004;75:667-672.

15 Siegmund EA, Cadmus RA, Lu G: A method for evaluating both non-narcotic and narcotic analgesics. Proc Soc Exp Biol 1957;95: 729-731.
16 Hendershot LC, Forsaith J: Antagonism of the frequency of phenylbenzoquinone induced writhing in the mouse by weak analgesics and non-analgesics. J Pharmacol Exp Ther 1959;125:237-240.

17 Dambisya YM, Lee TL, Sathivalu V, Mat Jais AM: Influence of temperature, $\mathrm{pH}$ and naloxone on the antinociceptive activity of Channa striatus (haruan) extracts in mice. J Ethnopharmacol 1999;66:181-186.

18 Hosseinzadeh H, Amel S: Antinociceptive effects of the aerial parts of Salvia nemorosa L. extracts in mice. Arch Iranian Med 2000; 3:81-84.

19 Calixto JB, Beirith A, Ferreira J, Santos AR, Cechine Filho V, Yunes RA: Naturally occurring anti-nociceptive substances from plants. Phytother Res 2000;14:401-418.

20 Bittar M, de Souza MM, Yunes RA, Lento R, Delle Monache F, Cechinel Filho V: Antinociceptive activity of I3,II8-binaringenin, a biflavonoid present in plants of the Guttiferae. Planta Med 2000;66:84-86.

21 Galati EM, Monforte MT, Kirjavainen S, Forestieri AM, Trovato A, Tripodo MM: Biological effects of hesperidin, a citrus flavonoid. Note I: Anti-inflammatory and analgesic activity. Farmaco 1994;40:709-712.

22 Ramesh M, Rao YN, Rao AV, Prabhakar MC, Rao CS, Muralidhar N, Reddy BM: Antinociceptive and anti-inflammatory activity of a flavonoid isolated from Caralluma attenuata. J Ethnopharmacol 1998;62:63-66. 